\title{
CUBAN IMMIGRANTS IN THE UNITED STATES: WHAT DETERMINES THEIR EARNINGS DISTRIBUTION?*
}

\author{
Recibido: 08 de junio de 2016 • Aprobado: 03 de septiembre de 2016 \\ DOI: $10.22395 /$ seec.v19n41a1 \\ Aleida Cobas-Valdés** \\ Ana Fernández-Sainz *** \\ Stephen Wilkinson ${ }^{* * * *}$
}

\begin{abstract}
In this paper the conditional earnings distribution of Cuban immigrants in the U.S. using OLS and Quantile Regression is analyzed. The data used in the study come from the 2011 American Community Survey (ACS) in the U.S. provided by IPUMS (2011). The results show that increments in earnings associated with different socioeconomic characteristics such as: sex, marital status, ethnicity, proficiency in English and education vary across the earnings distribution.
\end{abstract}

\section{KEYWORDS}

Cuban migration; Earnings distribution; Cuban workers in U.S; Socioeconomic characteristics; Quantile Regression, Immigrants workers, Cuba.

JEL CODES

$\mathrm{C} 13, \mathrm{~J} 10, \mathrm{~J} 30, \mathrm{~J} 61$

\section{CONTENT}

Introduction; 1. Cubans in the U.S; 2. Methodology; 3. Empirical; 4. Conclusions, References.

Research Article. This article is part of PhD Dissertation of Aleida Cobas Valdés in partial fulfillment of the requirements for the $\mathrm{PhD}$ degree in Economics, under the supervision of the thesis tutor Ana Fernánez Sainz. Financial support from the Econometrics Research Group, Basque Government grant IT-642-13 is gratefully acknowledged and for the participants in the 2nd CIdE Workshop for PhD students in Econometrics and Empirical Economics (WEEE).

** Economist, University of Havana, Cuba. MSC in Economics, University of Basque Country, Spain. Researcher at Institute of Public Economic. University of the Basque Country, UPV/EHU. Avenida Lehendakari Aguirre 81, 48015. Bilbao. Bizkaia, Spain. E-mail: aleida.cobas@ehu.eus.

*** Economist, University of Basque Country UPV/EHU, Spain. PhD in Economics, University of Basque Country UPV/EHU, Spain. Full Professor of Econometrics, Department of Econometrics and Statistics (Applied Economic III). University of the Basque Country UPV/EHU., Spain. E-mail: ana.fernandez@ ehu.eus.

*** BA American Studies, Manchester University, U.K. PhD in Hispanic Studies. Queen Mary and Westfield College, University of London, U.K. Associate Lecturer, Department of Primary Care and Public Health Sciences King's College London School of Medicine 4th Floor, Capital House, 42 Weston Street LONDON, U.K. E-mail: s.wilkinson@cubastudies.org. 


\section{INMIGRANTES CUBANOS EN LOS ESTADOS UNIDOS: ¿QUÉ DETERMINA SU DISTRIBUCIÓN DE INGRESOS?}

\section{RESUMEN}

Este artículo analiza la distribución de ingresos condicionales de los inmigrantes cubanos en los Estados Unidos usando OLS y analizando una Regresión Cuantílica. Los datos usados en este estudio fueron tomados del American Community Survey (ACS) de los Estados Unidos y fueron suministrados por IPUMS (2011). Los resultados muestran que incrementos en los ingresos asociados a diferentes características socioeconómicas tales como: el sexo, estado civil, etnia, manejo del idioma inglés y educación varían entre las diferentes distribuciones de ingresos.

\section{PALABRAS CLAVE}

Migración cubana; Distribución de ingresos, trabajadores cubanos en los Estados Unidos; Características socioeconómicas, Regresión Cuantílica, Trabajadores inmigrantes. Cuba.

\section{CODIGOS JEL}

C13, J10, J30, J61

\section{CONTENIDO}

Introduction; 1. Cubanos en los Estados Unidos; 2. Methodologia; 3. Emperico; 4. Concluciones, Referencias.

\section{IMIGRANTES CUBANOS NOS ESTADOS UNIDOS: 0 QUE DETERMINA SUA DISTRIBUIÇÃO DE INGRESSOS?}

\section{RESUMO}

Este artigo analisa a distribuição de ingressos condicionais dos imigrantes cubanos nos Estados Unidos usando OLS e analisando uma Regressão Quantílica. Os dados usados neste estudo foram tomados do American Community Survey (ACS) dos Estados Unidos e foram subministrados por IPUMS (2011). Os resultados mostram que incrementos nos ingressos associados a diferentes características socioeconômicas tais como: o sexo, estado civil, etnia, manejo do idioma inglês e educação variam entre as diferentes distribuições de ingressos.

\section{PALAVRAS CHAVE}

Migração cubana; Distribuição de ingressos, trabalhadores cubanos nos Estados Unidos; Características socioeconômicas, Regressão Quantílica , Trabalhadores imigrantes. Cuba.

\section{CLASSIFICAÇÃO JEL}

C13, J10, J30, J61 


\section{INTRODUCTION}

In terms of education level, Cuban immigrants positively self-select in their migration decision, that is, the people with the highest levels of education are those who tend to migrate. In general, migrants have more years of study than the mean of distribution of years of study of workers in Cuba, according to Cobas and Fernández (2014), and therefore they are workers with extensive skills in their source country. In addition, when considering legal migration, there is a tendency for the U.S. government to grant visas to both younger and better qualified individuals.

Since it is the most highly skilled people who migrate, it is undoubtedly of interest to analyze the whole distribution of earnings and quantify the effect of socioeconomics variables in different location of the distribution of earnings.

Following to Motel and Patten (2012), the United States has been the main destination for migrants from Cuba, and other Latin American countries. The U.S. Census for 2012 reveals that 52,4 million people (16,95\% of the entire population) in the United States are of Hispanic origin (U.S. Census Bureau, 2012); 1,12 million of them, i.e. $3 \%$ of the foreigners living in the U.S. were born in Cuba.

It is well known that an important proportion of the labor force in the U.S. is made up of immigrants. According to the U.S. Bureau of Labor Statistics (2013) in 2012 0,6 \% of U.S. workers comprised people of Latin ethnicity, Cubans made up 5 $\%$, making them the third biggest group of Hispanic immigrants in the U.S.

In line with Friedberg (1992), upon arrival in the U.S., immigrants can be expected to be at an earnings disadvantage with respect to natives because they lack certain skills and information that natives have. Over time, they may increase their income when they improve their English and adapt to the specific skill sets of the country.

In step with Aupetit and Gérard (2009), the migration of higher educated individuals has a negative impact on countries of birth since most educational investment on migrants is lost. Following to Cuecuecha (2005), in terms of benefits to the host country, migration increases its production capacity and technological capabilities, and from an economic point of view entails no significant costs in terms of social services, which would be required if the majority of those who migrated had less education.

This paper describes the earnings of Cuban immigrants in the U.S. using Ordinary Least Square (OLS) and Quantile Regression (OR). Quantile Regression is a method for estimating the relationship between a response variable and a set of explanatory variables for the whole conditional probability distribution of the response variable. 
The explanatory variables considered are those that areconsidered as most important in the relevant literature: years of education, age on arrival in the U.S., potential job experience, sex, marital status, ethnicity, citizenship status and proficiency in English. The applications of OR range from the field of education; like the studies of Rangvid (2007), to biostatistics; like Terry, Wei and Esserman (2007) and economics like Chamarbagwala (2010).

Some papers, using cross-section models, have tended to confuse the true assimilation of immigrants in the U.S. labor market. Chiswick (1978) found that the wage of Cubans immigrants in the U.S. who arrived in 1965-1969 increased by about 37 $\%$ within the first 10 years after immigration. This could lead to the conclusion that the earnings of immigrants grow rapidly and this rapid growth enables immigrants to overtake the earnings of native workers within 10-15 years of immigration. Borjas (1985) compared different cohorts, at the same points of their U.S. life cycle, using cross-section models within immigrant cohorts, and found that for the same period, 1965-1969, the earnings of Cuban immigrants decreased by about $25 \%$.

Some recent studies about earnings distribution of Latin immigrants in the U.S. reveal considerable disadvantages with respect to native-born people. Chiswick and Miller (2008) find that immigrants from non-English speaking countries have mean hourly earnings of around 12 \% less than those of native born workers in the U.S.; Elliott and Lindley (2008) concludes that differences in human capital endowment and socioeconomic characteristics explain some of the lack of earnings assimilation; Hunt (2012) concludes that non-English-speaking immigrants earn less than their native counterparts. Borjas (2015) finds that Cuban immigrants who arrived in the United States between 1995 and 1999 experienced a wage decrease of 4,4 \% in their first 10 years in the U.S.

The contribution of this article is twofold. Firstly, it uses QR method to estimate the effects of different socioeconomic characteristics on the conditional probability distribution of the earnings of Cuban immigrants in the U.S. to analyze the distribution of earnings of Cuban immigrants in the U.S. and quantify the effect of this socioeconomic variables. Secondly, it illustrates the differences in the impact of these characteristics between higher and lower income workers. Taking into account that a OR model proposes different regression lines for the different quantiles of the earnings distribution, the contribution of the socioeconomics characteristics on different levels of earnings can be compared.

The paper is structured as follows: Section 1 reviews the presence of Cubans in the U.S., Section 2 describes the methodology used, Section 3 presents the results of our estimations and Section 4 sets out the main conclusions. 


\section{CUBANS IN THE U.S.}

Although most of the population of Cuban origin in the U.S. have arrived within the past 50 years, the Cuban presence in the country has a long history. According to Pérez (1986), between 1871 and 1958 some 221.000 Cubans migrated to the U.S., mainly to Florida, the most proximate state to the island. Following to Pérez (2001) this figure is dwarfed by the approximately 1,25 million Cubans who have migrated to United States since 1959. This exodus has also been mainly to Florida, particularly Miami, where approximately three out of every five Cubans in the U.S. reside. Unlike most ethnic groups in other cities, overrepresented in only a few sectors of the economy, the presence of Cubans has been widespread in the Miami economy, Portes and Shafer (2007) state.

There have been five distinct periods of Cuban migration: The first was from 1959-1962, when around 200.000 Cubans migrated generally from the upper classes; the second period lasted from 1965-1973, when the U.S. conducted "freedom flights" and 260.500 applicants were permitted to leave the country in airlifts sponsored by the U.S.

According to Pérez (2001), the third wave came in 1980-1981, known as the Mariel boatlift period when some 125.000 Cubans migrated, including those from lower socioeconomic classes. Then came the so-called Balseros Crisis of 1994, when Cuba announced it would not restrain Cubans from leaving the country by raft or sea vessels and, consequently, over 40.000 balseros successfully migrated to the U.S.

The final period, from 1995 to the present, has been characterized by a steady outflow of some 20-30.000 Cubans migrating legally every year to the U.S. under accords reached following the Balseros Crisis. In addition, there has been a smaller, but unquantifiable number of Cubans migrating illegally'. Krogstad (2016) assures that the number of Cubans who have entered the U.S. has spiked dramatically since President Obama announced the renewal of relations with Cuba in 2014 with a 78 $\%$ increase in the number of illegal Cuban migrants entering the U.S., reportedly the largest wave of migration since the 1990s.

Thus around 1,5 million Cubans have immigrated to the United States since the 19th Century, settling predominately in Miami. They dominate the political scene in South Florida and have more recently become a leading demographic in political elections in the twenty-first century. Their success in the United States, according

This illegal migration has been exacerbated by U.S. policy of admitting illegal migrants of Cuban origin who manage the enter U.S. territory. This so called 'wet foot, dry foot' policy incentivises illegal migration and has resulted in significant human trafficking through Central America and Mexico and is the cause of serious friction between migrants of Haitian origin, who do not benefit from the same policy. See for example Pérez (2004). 
to Krogstad (2016), is partly due to the favorable treatment that Cubans receive as a consequence of The Cuban Adjustment Act, U.S. legislation passed during the Cold War to assist Cubans fleeing from communism and partly due to factors inherent in their distinct demographic characteristics.

Following the study of Pérez (2001), until the end of the 1990s, Cubans were the oldest, wealthiest and most educated Latino immigrants in the United States. In 2000, the median age of Cubans was 41,3 years, more than ten years older than the next eldest who were Central and South Americans, averaging 29,9 years of age. Furthermore, 24,8 percent of Cubans held a bachelor's degree compared with 18,0 percent of Central and South Americans. One in four Cubans 25 and older is a college graduate, more than double the rate of other Hispanics.

Finally, Suárez-Orozco and Páez (2002) state that Cuban Americans are more educated than other Latinos, and native-born Cubans show higher rates of college graduation than non-Hispanic whites. Otherwise, Hernández and Foladori (2014) assure since the turn of the century, the trend has been for younger (aged 20-40) and more highly qualified professional Cubans to migrate.

\section{METHODOLOGY}

Many of the issues that social researchers are currently analyzing, are related to the values of variables of interest located at the tails of the distribution of the variable of interest. The Quantile Regression (OR) method proposed in this paper measures the effect of the explanatory variables at various points of the (log) hourly earnings distribution. The difference at various quantiles provides significant information about the effects of the covariates considered on the hourly earnings spread. A linear quantile regression model ${ }^{2}$ links the conditional quantiles of the response variable to the covariates linearly.

With this method it is possible to study the conditional distribution of the (log) hourly earnings over the different socioeconomic variables at different locations and thus provide an overview of the links between (log) hourly earnings and the socioeconomic variables selected for the study.

As pointed out in Machado and Mata (2005) the estimated Quantile Regression coefficients can be interpreted as rates of return of labor market skills at different points of the conditional wage distribution. In general, the parameter estimated in linear quantile regression models have the same interpretation as those in any other linear regression model but now defined for a specified quantile, as Koenker (2005) says.

\footnotetext{
See Koenker and Basset (1978)
} 
A robust OLS estimation on Equation (1) employing the heteroskedasticity robust HC4 estimator of Cribari-Neto (2004) was initially carried out. This estimator improves sample performance when the term of error is independent but heteroskedastic, especially in the presence of influential observations (Zeileis, 2004).

$$
w_{i}=x_{i}^{\prime} \beta+\varepsilon_{i} \quad i=1, \ldots, n
$$

Where $w_{i}$ is the logarithm of gross hourly earnings for individual $i$, using total pre-tax wage and salary income (expressed in contemporary dollars), i.e, money received as an employee for the previous year as the measure of earnings; $x_{i}$ is a vector of socioeconomics characteristics of Cuban immigrants in the U.S. including an intercept, $\varepsilon_{i}$ is the error term and $\beta \in \mathbb{R}^{\mathrm{m}}$ is a vector of unknown parameters.

Next, the proposed model in Equation (1) under the conditional Quantile Regression $(\mathrm{QR})$ is estimated. For any $\mathrm{t} v(0,1)$ a linear quantile regression model can be written as

$$
w_{i}=\chi_{i}^{\prime} \beta_{\tau i}+\varepsilon_{\tau i}
$$

The quantile function $\mathrm{O}_{w i}\left(\tau \mid x_{i}\right)$ of the response variable wi conditional on covariate vector $x_{i}$ at a given quantile parameter $\tau$ is given by

$$
Q_{w i}\left(\tau \mid x_{i}\right)=x_{i}^{\prime} \beta_{\tau}
$$

No specific assumptions are made for the error term, apart from $\varepsilon_{\tau i}$ and $\varepsilon_{\tau j}$ being independent for $i \neq j$ and to consider that the distribution function at 0 is $\tau$. The estimation of regression quantiles coefficients, $\beta_{\tau}$, can differ across the different $\tau$ -quantiles $\tau$, so the marginal effect of a particular explanatory variable may not be homogeneous across the quantiles.

Since all continuous explanatory variables are centered at their median value, we use the centercept concept of Wainer (2000).

\section{EMPIRICAL RESULTS}

The data used in this paper come from the random sample of $1 \%$ of the 2011 American Community Survey (ACS) provided by Integrated Public Use Microdata Series (2011) This sample includes only individuals who entered the U.S. at the age of 17 years or

\footnotetext{
The data have been collected from the Integrated Public Use Microdata Series, Minnesota Population Center, of the University of Minnesota. The database used in the research is available for any researcher who requests through the web page: https://usa.ipums.org/usa/, or it can be provided by the authors through the e-mail: aleida.cobas@ehu.eus.
} 
over. This approach is intended to exclude people who completed their education in U.S, as Lowell, Pederzini and Passel (2008) state.

In addition, only individuals who entered the U.S. when less than 50 years old are considered, since the assumption is that the group aged between 16 and 49 years consists of those most likely to migrate for economic reasons, as Bertoli, Fernández-Huertas and Ortega (2013) point out in their study. Only individuals in work and those aged between 25-64 at the time of the survey are considered.

The sample consists of 19.079 observations. Table 1 gives a summary of the variables considered in the estimation models for Cubans immigrants in the U.S. As can be seen, $43 \%$ of the people in the sample are women, $63 \%$ are married, $45 \%$ are nationalized in the U.S., $53 \%$ speak English well or very well and approximately $3 \%$ are black. $50 \%$ of Cubans in the U.S. were 30 years old or more at the time of their entry into the U.S., have 12 or more years of education and earn $\$ 8,33$ per hour or more. On average they have 27 years of potential experience.

Table 1. Statistics of covariates: Mean and Standard Deviation. ${ }^{4}$

\begin{tabular}{llcc}
\hline \multicolumn{1}{c}{ Variable } & \multicolumn{1}{c}{ Description } & Mean & Standard Deviation \\
\hline Woman & Dummy variable: 1 if woman & 0,4264 & 0,4946 \\
Black & Dummy variable: 1 if black & 0,0309 & 0,1730 \\
Married & Dummy variable: 1 if married & 0,6283 & 0,4833 \\
AmericanCitizen & Dummy variable: 1 if an American citizen & 0,4461 & 0,4971 \\
EnglishProficiency & Dummy variable: 1 if proficiency in English & 0,5314 & 0,4990 \\
AgeImm & Age of the individual (in years) at time of & 29,81 & 8,2119 \\
YearsEducation & migration & 12,46 & 2,9781 \\
Experience & Years of Education of the individual & 27,43 & 11,5426 \\
Log Hourly Earnings & Response Variable & 2,6219 & 0,7724 \\
\hline
\end{tabular}

Source: Author's own elaboration based on the 2011 American Community Survey (ACS) in the U.S. provided by IPUMS (2011).

Figure 1 and 2 show where individuals work depending on their level of education. We considered whether individuals in Cuba and in the U.S. held jobs with a professional category in line with their education level. A comparison of the occupation of Cubans in Cuba and Cubans in the United States reveals that a higher percentage of Cubans in U .S. with 13 or more years of education work in jobs that require lower skills than they actually possess.

4 Potential Experience of the individuals = Age-Years of Education -6 
Figure 1. Job Category in Cuba

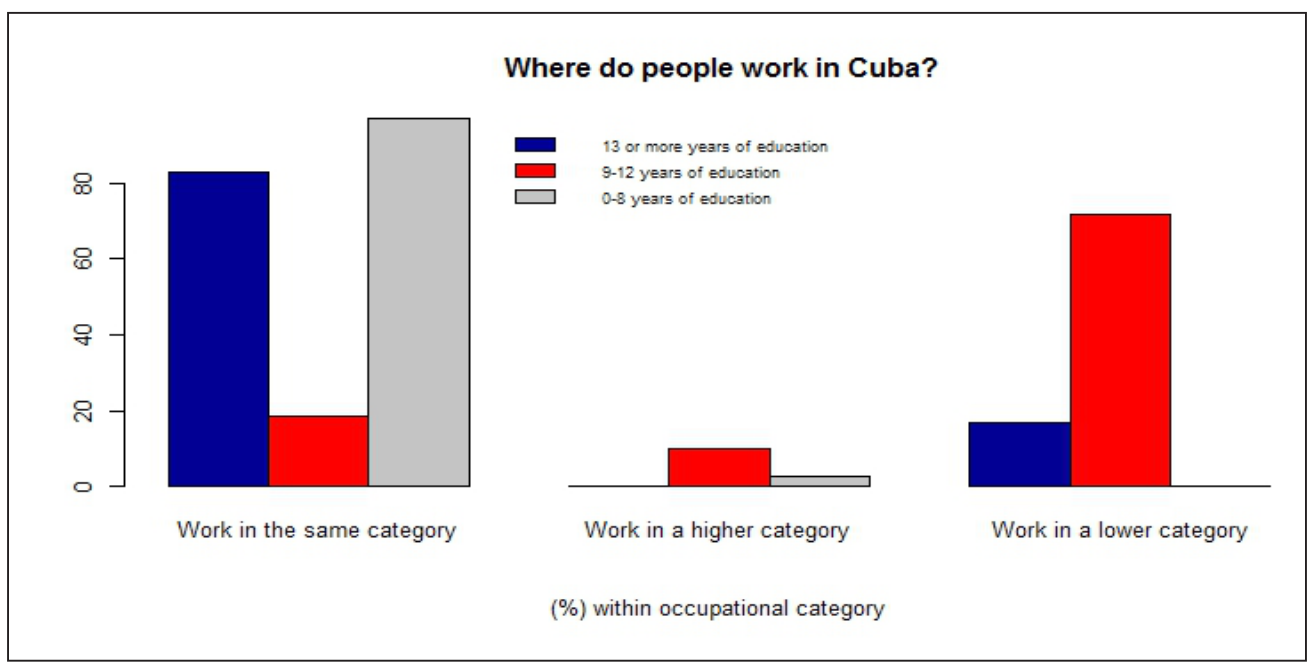

Source: Author's own elaboration based on the Population and Housing Census of Cuba 2002 provided by IPUMS-International (2011).

Figure 2. Job Category in the U.S.

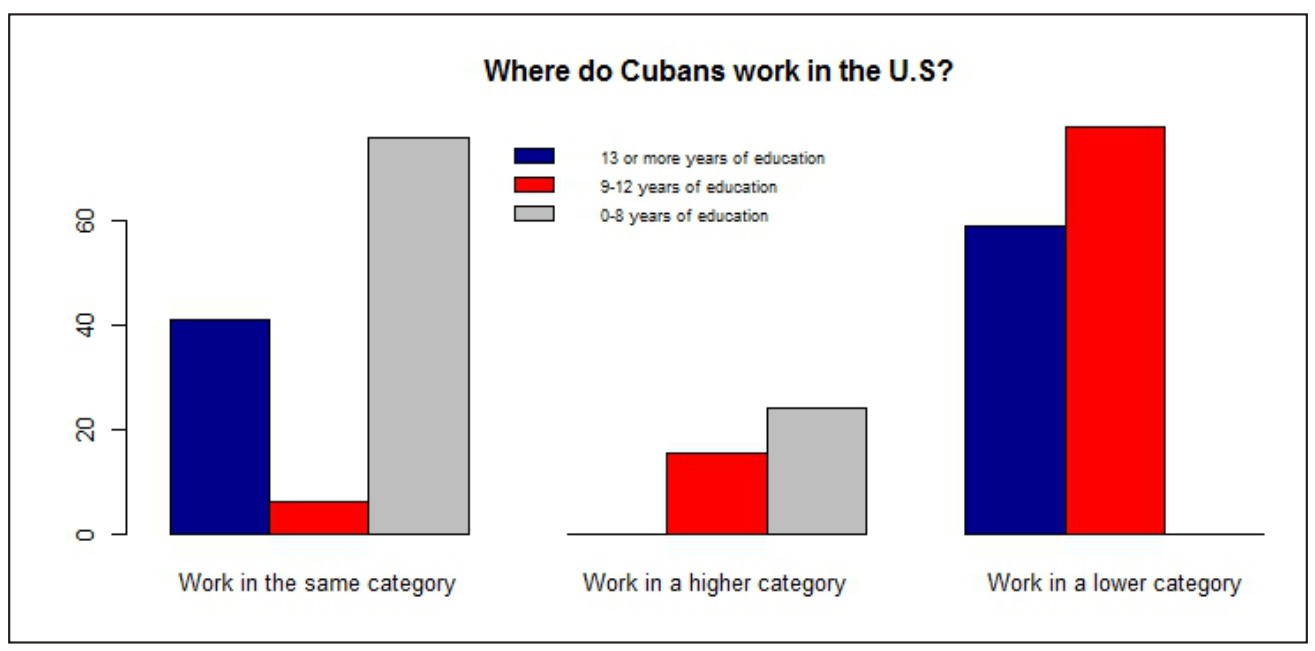

Source: Author's own elaboration based on the 2011 American Community Survey (ACS) in the U.S. provided by IPUMS (2011).

Figure 3 presents a histogram and box plot of (log) hourly earnings for Cuban immigrants. The histogram of (log) hourly earnings gives a good picture of the presence of positive skewness. 
Figure 3. Histogram and Box Plot of (log) Hourly Earnings.

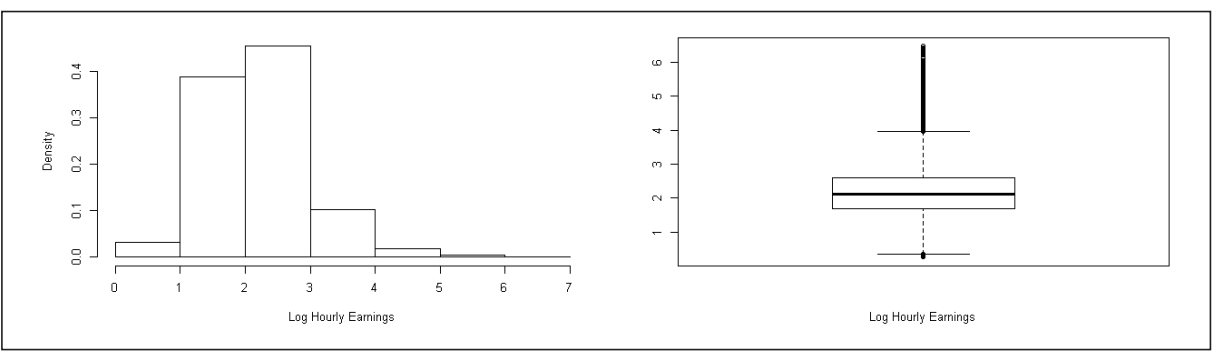

Source: Author's own elaboration based on the 2011 American Community Survey (ACS) in the U.S. provided by IPUMS (2011).

Following to Cobas and Fernández (2014), nearly 60 \% of Cubans in the United States who have 13 or more years of education take jobs with low skill requirements and $78 \%$ of those with 9-12 years of education work as skilled workers. In the same line, Cattan (1993) assures that many Cubans begin their working life in U.S. in jobs with skill levels much lower than and very different from those that they held in Cuba.

Table 2 contains the sample correlations between the explanatory variables. As can be seen, there are significant correlations between Proficiency in English and Citizenship Status ( $r=0,3387$ ), that is, Cubans with greater Proficiency in English are more likely to be citizens. Age on arrival in the U.S. and proficiency in English are negatively associated $(r=-0,3611)$; this means that younger individuals seem to be the most predisposed to learn English.

Table 2. Sample correlation of variables

\begin{tabular}{|c|c|c|c|c|c|c|c|c|}
\hline & Woman & Black & Married & $\begin{array}{c}\text { American } \\
\text { Citizen }\end{array}$ & $\begin{array}{c}\text { English } \\
\text { Proficiency }\end{array}$ & AgeImm & $\begin{array}{l}\text { Years of } \\
\text { Education }\end{array}$ & Experience \\
\hline Woman & 1,0000 & $-0,0200$ & $-0,0353$ & 0,1118 & 0,0198 & $-0,0945$ & 0,0443 & 0,0324 \\
\hline Black & & 1,0000 & $-0,0483$ & $-0,0401$ & $-0,0073$ & 0,0311 & $-0,0278$ & $-0,0111$ \\
\hline Married & & & 1,0000 & 0,0622 & $-0,0145$ & 0,0439 & $\begin{array}{r}0,0121 \\
*\end{array}$ & 0,0638 \\
\hline $\begin{array}{l}\text { American } \\
\text { Citizen }\end{array}$ & & & & 1,0000 & 0,3387 & $-0,2659$ & 0,1208 & 0,4033 \\
\hline $\begin{array}{l}\text { English } \\
\text { Proficiency }\end{array}$ & & & & & 1,0000 & $-0,3611$ & 0,2916 & $-0,0115$ \\
\hline AgeImm & & & & & & 1,0000 & $-0,0404$ & 0,2292 \\
\hline $\begin{array}{l}\text { Years of } \\
\text { Education }\end{array}$ & & & & & & & 1,0000 & $-0,2925$ \\
\hline Experience & & & & & & & & 1,0000 \\
\hline
\end{tabular}

Note: All correlations are significant at the $1 \%$ significance level. * means significant only at the $10 \%$ significance level.

Source: Author's own elaboration based on the 2011 American Community Survey (ACS) in the U.S. provided by IPUMS (2011). 
As can be seen in the first column of Table 3, in the OLS estimation there is only one non-significant explanatory variable (Black) to explain the (log) hourly earnings, at the significance leel of 5\%. The remaining explanatory variables are statistically significant. Note that being married, being a naturalized American, speaking English well or very well, years of education and potential job experience show a positive link to (log) hourly earnings, while being a woman and age on entry in the U.S. show a negative link to the response variable.

Table 3. OLS and Linear Quantile Regression.

\begin{tabular}{|c|c|c|c|c|c|c|}
\hline \multicolumn{7}{|c|}{ Dependent variable: Log Hourly Earnings } \\
\hline & OLS & $10 \%$ & $25 \%$ & $50 \%$ & $75 \%$ & $90 \%$ \\
\hline Centercept & $\begin{array}{l}2,1266 \\
(0,0134)^{* * *}\end{array}$ & $\begin{array}{l}1,3763 \\
(0,0180)^{* * *}\end{array}$ & $\begin{array}{l}1,6915 \\
(0,0143)^{* * *}\end{array}$ & $\begin{array}{l}2,0707 \\
(0,0142)^{* * *}\end{array}$ & $\begin{array}{l}2,4683 \\
(0,0184)^{* * *}\end{array}$ & $\begin{array}{l}2,9478 \\
(0,0298)^{* * *}\end{array}$ \\
\hline IsWoman & $\begin{array}{l}-0,2839 \\
(0,0108)^{* * *}\end{array}$ & $\begin{array}{l}-0,2626 \\
(0,0141)^{* * *}\end{array}$ & $\begin{array}{l}-0,3128 \\
(0,0109)^{* * *}\end{array}$ & $\begin{array}{l}-0,3256 \\
(0,0109)^{* * *}\end{array}$ & $\begin{array}{l}-0,2889 \\
(0,0144)^{* * *}\end{array}$ & $\begin{array}{l}-0,2355 \\
(0,0230)^{* * *}\end{array}$ \\
\hline IsBlack & $\begin{array}{l}-0,0377 \\
(0,0323)\end{array}$ & $\begin{array}{l}-0,0646 \\
(0,0266)^{* *}\end{array}$ & $\begin{array}{l}-0,0992 \\
(0,0344)^{* *}\end{array}$ & $\begin{array}{l}-0,0344 \\
(0,0354)\end{array}$ & $\begin{array}{l}-0,0310 \\
(0,0326)\end{array}$ & $\begin{array}{l}0,0946 \\
(0,0824)\end{array}$ \\
\hline IsMarried & $\begin{array}{l}0,0654 \\
(0,0108)^{* * *}\end{array}$ & $\begin{array}{l}0,0709 \\
(0,0143)^{* * *}\end{array}$ & $\begin{array}{l}0,0710 \\
(0,0114)^{* * *}\end{array}$ & $\begin{array}{l}0,0683 \\
(0,0109)^{* * *}\end{array}$ & $\begin{array}{l}0,0688 \\
(0,0145)^{* * *}\end{array}$ & $\begin{array}{l}0,0547 \\
(0,0226)^{* *}\end{array}$ \\
\hline IsAmericanCitizen & $\begin{array}{l}0,0884 \\
(0,0133)^{* * *}\end{array}$ & $\begin{array}{l}0,1029 \\
(0,0194)^{* * *}\end{array}$ & $\begin{array}{l}0,1111 \\
(0,0141)^{* * *}\end{array}$ & $\begin{array}{l}0,0898 \\
(0,0135)^{* * *}\end{array}$ & $\begin{array}{l}0,0871 \\
(0,0171)^{* * *}\end{array}$ & $\begin{array}{l}0,0024 \\
(0,0288)\end{array}$ \\
\hline EnglishProficiency & $\begin{array}{l}0,1564 \\
(0,0118)^{* * *}\end{array}$ & $\begin{array}{l}0,0992 \\
(0,0162)^{* * *}\end{array}$ & $\begin{array}{l}0,1514 \\
(0,0123)^{* * *}\end{array}$ & $\begin{array}{l}0,1577 \\
(0,0121)^{* * *}\end{array}$ & $\begin{array}{l}0,1432 \\
(0,0157)^{* * *}\end{array}$ & $\begin{array}{l}0,1824 \\
(0,0260)^{* * *}\end{array}$ \\
\hline Agelmm & $\begin{array}{l}-0,0110 \\
(0,0008)^{* * *}\end{array}$ & $\begin{array}{l}-0,0087 \\
(0,0011)^{* * *}\end{array}$ & $\begin{array}{l}-0,0113 \\
(0,0008)^{* * *}\end{array}$ & $\begin{array}{l}-0,0121 \\
(0,0008)^{* * *}\end{array}$ & $\begin{array}{l}-0,0114 \\
(0,0010)^{* * *}\end{array}$ & $\begin{array}{l}-0,0119 \\
(0,0017)^{* * *}\end{array}$ \\
\hline Years of Education & $\begin{array}{l}0,0623 \\
(0,0023)^{* * *}\end{array}$ & $\begin{array}{l}0,0425 \\
(0,0030)^{* * *}\end{array}$ & $\begin{array}{l}0,0525 \\
(0,0023)^{* * *}\end{array}$ & $\begin{array}{l}0,0653 \\
(0,0024)^{* * *}\end{array}$ & $\begin{array}{l}0,0727 \\
(0,0029)^{* * *}\end{array}$ & $\begin{array}{l}0,0751 \\
(0,0049)^{* * *}\end{array}$ \\
\hline Experience & $\begin{array}{l}0,0046 \\
(0,0006)^{* * *}\end{array}$ & $\begin{array}{l}0,0009 \\
(0,0009)\end{array}$ & $\begin{array}{l}0,0038 \\
(0,0006)^{* * *}\end{array}$ & $\begin{array}{l}0,0053 \\
(0,0006)^{* * *}\end{array}$ & $\begin{array}{l}0,0054 \\
(0,0008)^{* * *}\end{array}$ & $\begin{array}{l}0,0075 \\
(0,0013)^{* * *}\end{array}$ \\
\hline $\begin{array}{l}\text { Years of Education } \\
\text { Sqd. }\end{array}$ & $\begin{array}{l}0,0051 \\
(0,0003)^{* * *}\end{array}$ & $\begin{array}{l}0,0029 \\
(0,0004)^{* * *}\end{array}$ & $\begin{array}{l}0,0041 \\
(0,0003) * * *\end{array}$ & $\begin{array}{l}0,0054 \\
(0,0004)^{* * *}\end{array}$ & $\begin{array}{l}0,0063 \\
(0,0004)^{* * *}\end{array}$ & $\begin{array}{l}0,0064 \\
(0,0008)^{* * *}\end{array}$ \\
\hline Experience Sqd. & $\begin{array}{l}-0,0003 \\
(0,00004)^{* * *}\end{array}$ & $\begin{array}{l}-0,0003 \\
(0,00005)^{* * *}\end{array}$ & $\begin{array}{l}-0,0003 \\
(0,00004)^{* * *}\end{array}$ & $\begin{array}{l}-0,0003 \\
(0,00004)^{* * *}\end{array}$ & $\begin{array}{l}-0,0003 \\
(0,00006)^{* * *}\end{array}$ & $\begin{array}{l}-0,0002 \\
(0,00009)^{* *}\end{array}$ \\
\hline
\end{tabular}

Significance Codes. ${ }^{* * *} 0,001 * * 0,05 * 0,10$. Standard Errors in parentheses.

Source: Author's own elaboration based on the 2011 American Community Survey (ACS) in the U.S. provided by IPUMS (2011).

The estimate of the return to years of education on the mean earnings is lower than expected, equal to 6,23 \%. An additional year of potential job experience is 
shown to increase mean earnings by $0,46 \%$. Being a woman decreases mean earnings by $28,39 \%$ which is the greatest decrease in mean earnings. The model explains approximately $15 \%$ of the variance in (log) hourly earnings.

Figure 4. Quantile Regression.

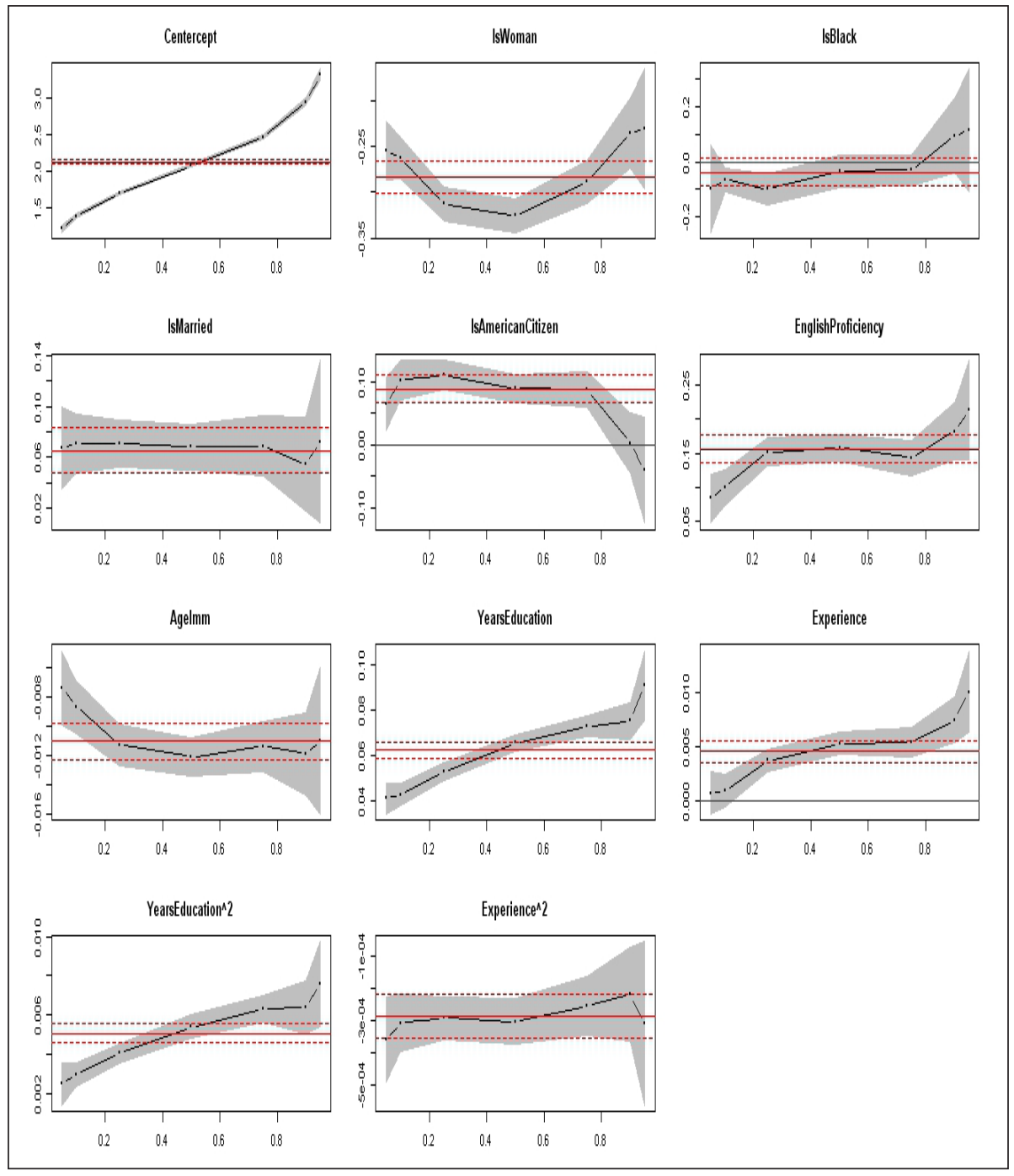

Source: Author's own elaboration based on the results of QR estimation.

Figure 4 shows the Quantile Regression results and Table 3 presents the Quantile regression estimations for five values of $\tau$-quantiles: 0,$10 ; 0,25 ; 0,50 ; 0,75$ and 0,90 . Increments in earnings associated with the different socioeconomic characteristics 
vary across the earnings distribution ${ }^{52}$. Being a woman causes a decrease in wages in all quantiles of the distribution, the decrease is highest from the 25th percentile to the 75th percentile. On average, women in the United States are paid just 77 cents for every dollar paid to men. For Latinas, the gap is larger. Latinas in the United States are paid, on average, just 54 cents for every dollar paid to white, non-Hispanic men (Fry and Taylor, 2013).

Being black is not a variable that explains the variability of (log) hourly earnings from the central part of the distribution to the upper part, since it is not a significant predictor in any percentile from the median at a significance level of 5\%. For people who earn less it is a significant predictor and it causes decreases in earnings. Being married is a variable that produces a homogeneous effect on the different quantiles of the distribution. Being an American citizen has little effect on hourly earnings and only a minor effect in the upper quantiles.

The return to proficiency in English is higher for people who earn more. For the 90-th percentile it gives rise to an increase in hourly earnings of about $18 \%$ compared to around $10 \%$ for the 10-th percentile. In line with Lazear (1999) the payoff for immigrants from learning the English language is likely to depend on the frequency with which they will use those skills in their everyday interactions. Borjas (2015) shows that more recent immigrants to the U.S. are improving their English language skills at a far lower rate than earlier immigrants.

Regarding age on entry in the U.S, being younger is more important in the upper quantiles of the distribution of earnings. The return to potential experience is almost zero across the distribution of earnings of workers, but it is greater for people who earn more.

The number of years of education has a smaller impact on earnings in the lower quantiles ( $4,25 \%$ for 10 th percentile and $5,25 \%$ for 25 th percentile) than in the upper quantiles (7,27 \% for the 75 th percentile and $7,51 \%$ for the 90 th percentile).

The returns to education are higher at the top of the conditional earnings distribution but lower than expected. One possible explanation for this situation is related to over-education. In this line, Martins and Pereira (2004) state lower earnings for over-educated workers increase the skill dispersion of pay by extending the lower tail of the wage distribution of the highly educated. In the same way, Bohon (2005) assures immigrants may also encounter difficulties in obtaining good jobs due to language barriers, less extensive network connections and lags in cultural adjustment.

Tests on whether these coefficients differ significantly from one point in the distribution to another have been performed and the null hypothesis of equality of coefficients is rejected the the significance level. 
Finally, Machado and Mata (2005) adds that another reason may be the fact that Cuban workers are not as highly valued in the U.S market now as they were years ago, due to increases in the emigration of highly skilled people. Skilled workers, earning relatively higher wages, have become relatively more abundant and, as a result, their relative wages have decreased.

\section{CONCLUSIONS}

This paper has analyzed the distribution of earnings of Cuban immigrants in the U.S in terms of certain observable characteristics: years of education, potential job experience, age at time of emigration, ethnicity, marital status, sex, citizenship status and proficiency in English. It uses the 2011 American Community Survey (ACS) of the U.S. provided by IPUMS (2011a). Within the sample, only workers aged between 25 and 64 years who immigrated to the United States when they were between 17 and 49 years old are considered.

For the analysis, Ordinary Least Squares (OLS) estimation with standard errors calculated using the heteroskedasticity robust HC-4 estimator of Cribari-Neto (2004) was first employed and then Quantile Regression, a technique which allows us to characterize the whole distribution of earnings of Cuban immigrants in U.S was proposed.

When we use OLS estimation with heteroskedasticy-robust standard errors, all explanatory variables except the fact of being black prove to be significant at the $5 \%$ significance level. All other variables being constant, speaking English well or very well is the variable that produces the biggest increase in mean hourly earnings at about $15,64 \%$; being a woman produces a decrease in mean hourly earnings of $28,39 \%$; being married produces an increase of about $6,54 \%$,; being a U.S citizen produces an increase of $8,84 \%$; one more year of study increases expected hourly earnings by $6,23 \%$ and one year of potential experience increases expected hourly earnings by $0,46 \%$.

However, the application of Quantile Regressions shows how the influence of the different variables considered on hourly earnings varies across the earnings distribution. With this type of estimation method differences between highly-skilled and low-skilled Cuban immigrants in the labour market can be detected.

The main conclusions of this article are the following: being a woman decreases hourly earnings at all points of the distribution, with the decrease being greater for individuals in the central part of the earnings distribution. The return to proficiency in English is greater for those people who earn more and the returns to education 
has a smaller impact on earnings in the lower quantiles and a greater impact at the top of the conditional earnings distribution but even then it is lower than expected. In particular, this article demonstrates how the return to education on earnings is less for Cuban born workers than expected.

\section{REFERENCES}

Aupetit, Sylvie Didou and Gérard, Etienne (2009). Fuga de cerebros, movilidad académica, redes científicas: Perspectivas latinoamericanas (primera ed.) México, DF: Centro de Investigación y de Estudios Avanzados del Instituto Politécnico Nacional, 237p.

Bertoli Simone; Fernández-Huertas, Jesús and Ortega, Francesc (2013). Crossing the Border: Self-Selection, Earnings and Individual Migration Decisions. In: Journal of Development Economics. Vol. 101, pp. 75-91.

Bohon, Stephanie A. (2005). Occupational Attainment of Latino Immigrants in the United States. In: Geographical Review. Vol. 95, No. 2, pp. 249-266.

Borjas, George J. (1985). Assimilation, Changes in Cohort Quality and the Earnings of Immigrants. In: Journal of Labor Economic. Vol. 3, No. 4, pp. 463-489.

Borjas, George J. (2015). The Slowdown in the Economic Assimilation of Immigrants: Aging and Cohort Effects Revisited Again. In: Journal of Human Capital Vol. 9, No. 4, pp. 483-517.

Cattan, Peter (1993). The diversity of Hispanics in the U.S. work force. In: Monthly Labor Review, Vol. 8, p. 3-15.

Chamarbagwala, Rubiana (2010). Economic liberalization and urban-rural inequality in India: a quantile regression analysis. In: Empirical Economics, Vol. 39, No. 2, pp. 371-394.

Chiswick, Barry R. (1978). The effect of Americanization on the earnings of foreign-born men. In: The Journal of Political Economy, Vol. 86, No 5, pp. 897-921.

Chiswick, Barry R. and Miller, Paul W. (2008). How immigrants fare across the earnings distribution in Australia and the United States. In: Industrial and Labor Relations Review, Vol. 61, No. 3, p. 353-373.

Cobas Valdés, Aleida and Fernández Sainz, Ana (2014). Cuban migration to the United States and the Educational Self-Selection Problem. In: International Journal of Cuban Studies, Vol. 6, No. 1, pp. 41-54.

Cribari-Neto, Francisco. (2004). Asymptotic Inference Under Heteroskedasticity of Unknown Form. In: Computational Statistics E Data Analysis, Vol. 45, No. 2, pp. 215-233.

Cuecuecha, Alfredo (2005). The Immigration of Educated Mexicans: The Role of Informal Social Insurance and Migration Costs. Working papers, Instituto Tecnológico Autónomo de México, No. 298, 64p.

Elliott, Robert and Lindley, Joanne (2008). Immigrant wage differentials, ethnicity and occupational segregation. In: Journal of the Royal Statistical Society: Series A (Statistics in Society), Vol. 171, No. 3, pp. 645-671. 
Friedberg, Rachel (1992). The Labor Market Assimilation of Immigrants in the United States: The Role of Age at Arrival. Working Paper, Brown University, 4lp.

Fry, Richard and Taylor, Paul (2013). Hispanic high school graduates pass whites in rate of college enrollment. Washington DC: Pew Research Center, 13p.

Hernández, Judith and Foladori, Guillermo (2014). The Population Dynamic Challenge to Cuban Socialism. In: International Journal of Cuban Studies, Vol. 6 No. 1, Special Edition: Population Dynamics in Contemporary Cuba (Spring), pp. 25-40.

Hunt, Priscillia (2012). From the bottom to the top: a more complete picture of the immigrant-native wage gap in Britain. In: IZA Journal of Migration, Vol. 1, No. 9, pp. 1-18.

IPUMS -Integrated Public Use Microdata Series- (2011). Steven Ruggles, J.; Trent,A.; Genadek K.; Goeken R.; Schroeder M.B. and Sobek, M., Version 5.0 [Machine-readable database]. Minneapolis: University of Minnesota.

IPUMS -Integrated Public Use Microdata Series- (2011a). Version 6.1 [Machine-readable database] Minnesota Population Center. Minneapolis: University of Minnesota.

Koenker, Roger and Bassett, Gilbert (1978). Regression Quantiles. In: Econometrica, Vol. 46, No. 1, pp. 33-50.

Koenker, Roger (2005). Quantile Regression, Cambridge, U.K.: Número 38 de Econometric Society Monographs, Econometric Society, ISSN 2059-2507, 349p.

Lazear, Edward P. (1999). Culture and Language. In: Journal of Political Economy, Vol. 107, No. S6, part 2, pp. S95-S125.

Lowell, B. Lindsay; Pederzini, Carla and Passel, Jeffrey (2008). The Demography of Mexico/U.S Migration, p. 1-32. In: Escobar A. y Martin, S.F. (edits). Mexico-U.S Migration Management: A Binational Approach. Maryland, Lexington Books, Series: Program in Migration and Refugee Studies, 240p.

Machado, José A.F and Mata, José (2005). Counterfactual Decomposition of Changes in Wage Distribution Using Quantile Regression. In: Journal of Applied Econometrics, Vol. 20, No. 4, pp. 445-465.

Martins, Pedro S. and Pereira, Pedro T. (2004). Does education reduce wage inequality? Quantile regression evidence from 16 countries. In: Labour Economics, Vol.11, No. 3, pp. 355-371.

Motel, Seth and Patten, Eileen (2012). Hispanic of Cuban Origin in the United States, 2010. Washington DC: Pew Research Center, 5p.

Pérez, Alberto J. (2004). Wet Foot, Dry Foot, No Foot: The RecurrinControversy Between Cubans, Haitians, and the United States Immigration Policy. In: Nova Law Review, Vol. 28, No. 2 pp. 436-465.

Pérez, Lisandro (1986). Cubans in the United States. In: The Annals of the American Academy of Political and Social Science, Vol. 487 (1), September, p. 126-137. Doi:10.1177/00027162 86487001008 . 
Pérez, Lisandro (2001). Growing up Cuban in Miami, p. 91-126. In: Rumbaut, R. and Portes, A. (edits). Ethnicities: Children of Immigrants in America. Los Angeles: University of California Press, 353p.

Krogstad, Jens Manuel (2016). Cuban immigration to U.S surges as relations warm. Washington DC: Pew Research Center, 3p.

Portes, Alejandro and Shafer, Steven (2007). Revisiting the enclave hypothesis: Miami twenty-five years later. In: Research in the Sociology of Organizations, Vol. 25, pp. 157-190. Doi:10.1016/ s0733-558x(06)25005-5.

Rangvid, Beatrice S. (2007). School composition effects in Denmark: Quantile regression evidence from PISA 2000. In: Empirical Economics, Vol. 33, No. 2, pp. 359-388.

Suárez-Orozco, Marcelo and Páez, Mariela (2002). Latinos: Remaking America. Los Angeles, University of California Press, 495p.

Terry, Mary B.; Wei, Ying and Esserman, Denise (2007). Maternal, Birth and early-Life Influences on Adult Body Size in Women. In: American Journal of Epidemiology, Vol.166, No. 1, pp. 5-13.

Wainer, Howard (2000). The Centercept: An Estimable and Meaningful Regression Parameter. In: Psychological Science. Vol. 11, No. 5, pp. 434-436.

Zeileis, Achim (2004). Econometric Computing with HC and HAC Covariance Matrix Estimators. In: Journal of Statistical Software, Vol. 11, No. 10, pp. 1-17. 
